\title{
Protein degradation during preimplantation development of the mouse
}

\author{
E. A. Merz*, R. L. Brinster, S. Brunner and H. Y. Chen \\ Laboratory of Reproductive Physiology, School of Veterinary Medicine, University of \\ Pennsylvania, Philadelphia, Pennsylvania 19104, U.S.A.
}

\begin{abstract}
Summary. The half-lives of labelled proteins were determined for mouse preimplantation embryo stages from the germinal vesicle oocyte to the early blastocyst. While no significant differences were found among half-lives for 1-cell stages, or among half-lives for cleavage stages, a significant $(P<0.05) 28 \%$ decrease in half-life was observed between the 1-cell and the cleavage stages. Labelled protein half-lives were 18.2 and $13.1 \mathrm{~h}$ for the 1-cell and cleavage stages respectively. Fertilization probably initiates this increase in protein degradation rate although no significant decrease was detected until after the first cleavage.
\end{abstract}

\section{Introduction}

Protein synthesis in mouse embryos has been measured at various developmental stages, from oocytes with intact germinal vesicles to blastocysts. Leucine incorporation into protein has generally been found to be low and constant throughout oocyte maturation (Cross \& Brinster, 1974; E.A. Merz and R.L. Brinster, unpublished), fertilization (Brinster, 1971; Brinster et al., 1976) and the 2-cell stage (Brinster, 1971; Epstein \& Smith, 1973; Brinster et al., 1976; Abreu \& Brinster, 1978). Schultz et al. (1979) have reported a decrease in the rate of protein synthesis during meiotic maturation and an increase after fertilization. However, agreement has been unanimous that the synthesis of protein increases dramatically between the 8-cell and blastocyst stages (Monesi \& Salfi, 1967; Brinster, 1971; Epstein \& Smith, 1973; Brinster et al., 1976; Abreu \& Brinster, 1978).

Unfortunately protein degradation has received considerably less attention, despite the fact that it is as important as synthesis in understanding protein metabolism (Brinster et al., 1976; 1979). Berlin \& Schimke (1965) and Schimke (1969) have emphasized this point in their studies on individual enzymes, They have demonstrated that the rate at which a protein approaches a new steady-state level following a change in synthetic or degradation rate is dependent on the degradation rate and not the synthetic rate. The final steady-state level reached depends on both the synthetic and degradation rates.

Because degradation is such an important aspect of protein metabolism, we have investigated this aspect of embryo proteins by studying the half-life of newly synthesized protein in various developmental stages of the mouse embryo.

* Present address: McNeil Laboratories, Fort Washington, Pennsylvania 19034, U.S.A. 


\section{Materials and Methods}

\section{General procedures}

Randomly bred female Swiss mice aged 6-8 weeks received a priming dose of 5 i.u. PMSG (Gestyl: Organon). After 48 h they were either killed for collection of oocytes or injected with 5 i.u. hCG (Sigma). Early 1-cell, 2-cell and 8-cell embryos were collected on Days 1 (day of finding the vaginal plug), 2 and 3 respectively. Cumulus cells were removed from oocytes and fertilized and unfertilized eggs by treatment with hyaluronidase ( 600 units $/ \mathrm{ml}$ ). General methods for the culture of embryos were as described previously (Brinster, 1963, 1972).

Oocytes at the germinal vesicle (GV) stage were collected into $6 \times 25 \mathrm{~mm}$ Petri dishes containing medium BMOC-3 (Brinster, 1972) after puncturing ovarian follicles with needles. Dibutyryl cyclic adenosine monophosphate (Sigma) was added to all dishes at a concentration of $100 \mu \mathrm{g} / \mathrm{ml}$ (Cho et al., 1974) when it was necessary to prevent germinal vesicle breakdown (GVB). Otherwise GV stage oocytes were collected and allowed to mature during labelling.

\section{Labelling procedure}

Embryos at all stages were labelled for $1 \mathrm{~h}$ in $50 \mu \mathrm{l}$ BMOC -3 containing $\left[{ }^{3} \mathrm{H}\right]$ methionine (sp. act. $80 \mathrm{Ci} / \mathrm{mmol}$ : New England Nuclear, Boston), at $5 \mathrm{mCi} / \mathrm{ml}$, then rinsed three times in $2.5 \mathrm{ml}$ volumes of BMOC-3 containing $5 \mathrm{mM}$ unlabelled methionine (BMOC-3-MET) and randomly allocated to six drops of BMOC-3-MET. Thus the rinse or chase medium, BMOC-3-MET, contained an 80-fold greater concentration of methionine than did the labelling medium. Two groups were immediately washed in two drops of BMOC-3-MET and one drop of phosphate-buffered saline containing $0.74 \mathrm{mg}$ polyvinylpyrrolidone $/ \mathrm{ml} \mathrm{(mol.} \mathrm{wt} 40000$ ) and 5 mM unlabelled methionine (PBS-PVP-MET) each. The embryos were then transferred in less than $5 \mu$ of the final wash to $3 \mathrm{ml}$ conical glass centrifuge tubes ( 0 -h samples). The remaining samples were transferred to second drops of BMOC-3-MET after $1 \mathrm{~h}$. Two groups were collected $1.5 \mathrm{~h}$ later after a rinse in one drop of PBS-PVP-MET ( $2.5-\mathrm{h}$ samples). The final two groups were similarly washed and collected $2.5 \mathrm{~h}$ after later (5-h samples). All samples were frozen immediately after collection and stored at $-70^{\circ} \mathrm{C}$.

\section{TCA precipitation}

The procedure reported by Brinster (1971) was used, with minor modifications, for trichloracetic acid precipitation of acid-insoluble proteins. After precipitation and washing of the protein in conical glass tubes, each tube was snapped in half and the bottom, containing the precipitate, was placed in a $20-\mathrm{ml}$ glass scintillation vial. Normal calf serum (NCS; $0.5 \mathrm{ml}$ ) (Amersham) was used to solubilize each precipitate. Vials were capped, incubated at $50^{\circ} \mathrm{C}$ for 1 $\mathrm{h}$, then cooled before addition of $9.5 \mathrm{ml}$ scintillation cocktail (LSC complete, Yorktown Research) to each.

Tritium disintegrations were counted in an Intertechnique SL 30 scintillation counter programmed to calculate disintegrations per minute (d.p.m.). Disintegrations per oocyte (egg or embryo) per minute were calculated and an exponential curve was fitted to the data (HP97 Stat Pac program) for each incubation to describe the decrease in labelled acid-precipitable protein over the 5 - $h$ chase period. Incubations were performed four times and a mean half-life was calculated for each stage.

\section{Results}

The effects on labelled protein half-life of addition of $100 \mu \mathrm{g}$ dibutyryl cAMP ml to the medium to inhibit GVB were examined. cAMP was added to all media used (GV oocytes), to none of the 
media used (GVB oocytes), or to the chase medium only (GVB-dibutyryl cAMP oocytes). Oocytes were collected at the GV stage for all groups, but allowed to mature during the 1-h labelling period for GVB and GVB-dibutyryl cAMP oocytes. The latter group was necessary to distinguish between the effects of germinal vesicle breakdown and dibutyryl cAMP.

The GV and GVB incubations, each done four times, yielded mean \pm s.e.m. half-lives of $16 \cdot 2 \pm 2 \cdot 1$ and $21 \cdot 3 \pm 3 \cdot 5 \mathrm{~h}$ respectively (Table 1 ). The GVB-dibutyryl cAMP incubation, run three times, gave an average half-life of $16.3 \pm 3.9 \mathrm{~h}$. One-way analysis of variance showed no significant differences among these values, indicating that neither germinal vesicle breakdown nor the addition of dibutyryl cAMP to media affected measurement of labelled protein half-life in oocytes.

The results for the different chase periods and embryo stages are given in Table 1. Duncan's new multiple range test (Steel \& Torrie, 1960) was performed to detect possible changes in labelled protein half-life following the physiologically significant events of germinal vesicle breakdown, ovulation, fertilization, initiation of cleavage and blastulation. A significant $(P<$ 0.05 ) decrease occurred after the initiation of cleavage, but no differences were found among the 1-cell stages or among the cleavage stages and overall mean labelled protein half-lives were calculated.

Table 1. Results (as d.p.m. per oocyte or embryo) for labelled (newly synthesized) protein of mouse developmental stages

\begin{tabular}{lcccc}
\hline & \multicolumn{3}{c}{ Duration of chase period } & Half-life \\
\cline { 2 - 5 } Embryo stage & $0 \mathrm{~h}$ & $2 \cdot 5 \mathrm{~h}$ & $5 \mathrm{~h}$ & $(\mathrm{~h})$ \\
\hline GV & $2927 \pm 106$ & $2590 \pm 97$ & $2335 \pm 99$ & $16 \cdot 2 \pm 2 \cdot 1$ \\
GVB & $2868 \pm 105$ & $2612 \pm 131$ & $2405 \pm 112$ & $21 \cdot 3 \pm 3 \cdot 5$ \\
Unfertilized ovum & $4410 \pm 70$ & $3873 \pm 66$ & $3635 \pm 91$ & $18 \cdot 1 \pm 1 \cdot 3$ \\
Fertilized egg & $4877 \pm 463$ & $4467 \pm 456$ & $3961 \pm 414$ & $17 \cdot 2 \pm 1 \cdot 9$ \\
$\quad$ Mean of 1-cell stages & & & & $18 \cdot 2^{*}$ \\
\hline 2-Cell & $2200 \pm 133$ & $1643 \pm 271$ & $1634 \pm 67$ & $12 \cdot 2 \pm 1 \cdot 5$ \\
8-Cell & $11307 \pm 1018$ & $9805 \pm 1191$ & $8743 \pm 860$ & $13 \cdot 8 \pm 1 \cdot 7$ \\
Blastocyst & $25645 \pm 1940$ & $21638 \pm 1300 \dagger$ & $20540 \pm 1730 \ddagger$ & $13 \cdot 3 \pm 1 \cdot 5$ \\
$\quad$ Mean of cleavage stages & & & $13 \cdot 1^{*}$ \\
\hline
\end{tabular}

$\mathrm{GV}=$ germinal vesicle intact; GVB = germinal vesicle broken down.

Values are mean \pm s.e.m. for 4 incubations of 2 tubes each.

* Significantly different, $P<0.05$.

+ Chase period $2 \mathrm{~h}$.

$¥$ Chase period $4 \mathrm{~h}$; the 6 -h value was $18311 \pm 1609$.

\section{Discussion}

There are only two earlier reports of protein half-life determinations in preimplantation mouse embryos. The data from the most recent of these (Brinster et al., 1979), on blastocyst labelled protein half-life $(12.4 \mathrm{~h})$, were actually incorporated into the present study. In the other study (Brinster et al., 1976) the half-life of newly synthesized proteins in 2-cell embryos was estimated to be $18.3 \mathrm{~h}$ and in blastocysts to be $11.2 \mathrm{~h}$. The values for the half-life in the blastocyst stage are similar in the different studies and close to the value of $13.1 \mathrm{~h}$ found for cleavage stages in the present study. The difference between the studies in the values for half-life of newly synthesized proteins in 2-cell embryos (18.3 and $12.2 \mathrm{~h}$ ) probably arises because the methods used in the two studies were not the same. One major difference was that the decay period was longer in the initial study, and the zygotes underwent cleavage. The long period in culture may have 
contributed to an inflated half-life estimate because of re-incorporation of labelled amino acid during the chase or because of changes in the cells from the extended culturing time. The values in the current study are based on more replicates and provide the more accurate comparison of half-lives between the different developmental stages.

The major alteration in half-life of labelled protein during the period studied is a $28 \%$ decrease associated statistically with the initiation of cleavage. However, it is possible that the signal for more rapid protein turnover actually occurs at the time of fertilization. The measurements of half-life were made shortly after fertilization and the alteration may not have progressed far enough to be detected in these embryos in the present studies. In any event, the decrease in half-life occurs very soon after fertilization and is clearly apparent by the early 2-cell stage of development. In contrast, the major increase (6-8-fold) in protein synthetic rate occurs later in development, between the 4-cell and blastocyst stage (Brinster, 1971; Epstein \& Smith, 1973; Brinster et al., 1976). A smaller increase in protein synthetic rate has been reported to occur at the time of fertilization (Schultz et al., 1979), but such an increase has not been found at fertilization in several other studies (Brinster, 1971; Cross \& Brinster, 1974; Brinster et al., 1976; Abreu \& Brinster, 1978).

Our finding that a significant decrease occurs in the degradation constant of the labelled protein pool documents an important alteration in embryo protein metabolism at or shortly after fertilization. This finding forms the basis for more detailed studies to examine the half-lives of individual proteins before and after fertilization. Such studies may help to identify proteins which play regulatory roles in differentiation by identifying those with rapid turnover.

Financial support was from a Public Health Services research grant (NICHHD 12384) and from a National Science Foundation research grant (PCM 78-22931). E.A.M., S.B. and H.Y.C. were trainees on NICHHD training grant HD 00239. We are grateful to Eleanor Lang for help in typing the manuscript.

\section{References}

Abreu, S.L. \& Brinster, R.L. (1978) Synthesis of tubulin and actin during the preimplantation development of the mouse. Expl Cell Res. 114, 135-141.

Berlin, C.M. \& Schimke, R.T. (1965) Influence of turnover rates on the responses of enzymes to cortisone. Mol. Pharmac. 1, 149-156.

Brinster, R.L. (1963) A method for in vitro cultivation of mouse ova from two-cell to blastocysts. Expl Cell Res. 32, 205-208.

Brinster, R.L. (1971) Uptake and incorporation of amino acids by the preimplantation mouse embryo. $J$. Reprod. Fert. 27, 329-338.

Brinster, R.L. (1972) Cultivation of the mammalian embryo. In Growth, Nutrition and Metabolism of Cells in Culture, Vol. II, pp. 251-286. Eds G. Robhblat \& V. Cristofalo. Academic Press, New York.

Brinster, R.L., Wiebold, J.L. \& Brunner, S. (1976) Protein metabolism in preimplanted mouse ova. Devl Biol. 51, 215-224.

Brinster, R.L., Brunner, S., Joseph, X. \& Levey, I.L. (1979) Protein degradation in the mouse blastocyst. J. biol. Chem. 254, 1927-1931.

Cho, W.K., Stern, S. \& Biggers, J.D. (1974) Inhibitory effect of dibutyryl cAMP on mouse oocyte maturation in vitro. J. exp. Zool. 187, 383-386.

Cross, P.C. \& Brinster, R.L. (1974) Leucine uptake and incorporation at three stages of mouse oocyte maturation. Expl Cell Res. 86, 43-46.

Epstein, C.J. \& Smith, S.A. (1973) Amino acid uptake and protein synthesis in preimplantation mouse embryos. Devl Biol. 33, 171-184.

Monesi, V. \& Salfi, V. (1967) Macromolecular synthesis during early development in the mouse embryo. Expl Cell Res. 46, 632-635.

Schimke, R.T. (1969) On the roles of synthesis and degradation in regulation of enzyme levels in mammalian tissues. In Current Topics in Cell Regulation, Vol. I, pp. 77-124. Eds B. L. Horecker \& E. R. Stadtman. Academic Press, New York.

Schultz, R.M., Letourneau, G.E. \& Wassarman, P.M. (1979) Program of early development in the mammal: Changes in patterns and absolute rates of tubulin and total protein synthesis during oogenesis and early embryogenesis in the mouse. Devl Biol. 68, 341-359.

Steel, R.D. \& Torrie, J.H. (1960) Principles and Procedures of Statistics. McGraw-Hill, New York. 